\title{
Hypervariable Region 1 in Envelope Protein 2 of Hepatitis C Virus: A Linchpin in Neutralizing Antibody Evasion and Viral Entry
}

\section{OPEN ACCESS}

Edited by:

Thomas F. Baumert, INSERM U1110 Institut de Recherche sur les Maladies Virales et Hépatiques,

France

Reviewed by:

Vanessa Marie Cowton MRC-University of Glasgow Centre

For Virus Research (MRC), United Kingdom

Florian Wrensch,

INSERM U1110 Institut de Recherche sur les Maladies Virales et Hépatiques,

France

*Correspondence:

Jannick Prentoe

jprentoe@sund.ku.dk

Jens Bukh

jbukh@sund.ku.dk

Specialty section:

This article was submitted to Vaccines and Molecular Therapeutics,

a section of the journal

Frontiers in Immunology

Received: 18 July 2018

Accepted: 30 August 2018

Published: 27 September 2018

Citation:

Prentoe $J$ and Bukh J (2018) Hypervariable Region 1 in Envelope Protein 2 of Hepatitis C Virus: A Linchpin in Neutralizing Antibody

Evasion and Viral Entry.

Front. Immunol. 9:2146. doi: 10.3389/fimmu.2018.02146

\begin{abstract}
Jannick Prentoe ${ }^{1,2 *}$ and Jens Bukh ${ }^{1,2 *}$
' Copenhagen Hepatitis C Program (CO-HEP), Department of Infectious Diseases, Hvidovre Hospital, Copenhagen, Denmark, ${ }^{2}$ Department of Immunology and Microbiology, Faculty of Health and Medical Sciences, University of

Copenhagen, Copenhagen, Denmark
\end{abstract}

Chronic hepatitis C virus (HCV) infection is the cause of about 400,000 annual liver disease-related deaths. The global spread of this important human pathogen can potentially be prevented through the development of a vaccine, but this challenge has proven difficult, and much remains unknown about the multitude of mechanisms by which this heterogeneous RNA virus evades inactivation by neutralizing antibodies (NAbs). The $\mathrm{N}$-terminal motif of envelope protein 2 (E2), termed hypervariable region 1 (HVR1), changes rapidly in immunoglobulin-competent patients due to antibody-driven antigenic drift. HVR1 contains NAb epitopes and is directly involved in protecting diverse antibody-specific epitopes on E1, E2, and E1/E2 through incompletely understood mechanisms. The ability of HVR1 to protect HCV from NAbs appears linked with modulation of HCV entry co-receptor interactions. Thus, removal of HVR1 increases interaction with CD81, while altering interaction with scavenger receptor class B, type I (SR-BI) in a complex fashion, and decreasing interaction with low-density lipoprotein receptor. Despite intensive efforts this modulation of receptor interactions by HVR1 remains incompletely understood. SR-BI has received the most attention and it appears that HVR1 is involved in a multimodal HCV/SR-BI interaction involving high-density-lipoprotein associated $\mathrm{ApoCl}$, which may prime the virus for later entry events by exposing conserved NAb epitopes, like those in the CD81 binding site. To fully elucidate the multifunctional role of HVR1 in HCV entry and NAb evasion, improved E1/E2 models and comparative studies with other NAb evasion strategies are needed. Derived knowledge may be instrumental in the development of a prophylactic HCV vaccine.

Keywords: hepatitis C virus (HCV), hypervariable region 1 (HVR1), viral entry, vaccine design, neutralization

\section{INTRODUCTION}

It is estimated that at least 2 million people become infected with hepatitis C virus (HCV) every year (1). The majority of these individuals will develop chronic infections adding to the more than 71 million chronically infected people worldwide, who are consequently at increased risk of developing liver diseases, such as cirrhosis and hepatocellular carcinoma $(1,2)$. HCV-related mortality is estimated at 400,000 people every year, and although direct-acting antiviral therapies with cure-rates $>95 \%$ are now available, treatment is often not accessible for multiple reasons, 
including frequent occult infection and high cost $(3,4)$. Thus, the development of a prophylactic vaccine is required to control $\mathrm{HCV}$ worldwide, but this challenge has proven difficult owing in part to the complex measures HCV employs to avoid the host immune responses (5).

$\mathrm{HCV}$ is an enveloped, positive-stranded RNA virus of the Hepacivirus genus in the Flaviviridae family $(6,7)$. The genome is $\sim 9.6$ Kilobases and encodes 10 functional viral proteins from a single polyprotein. Virus structural proteins form part of the virus particle with the Core protein assembling into the viral capsid that protects the HCV genome, and envelope proteins 1 and 2 (E1 and E2) imbedded in the viral envelope as the heterodimeric glycoprotein complex, E1/E2 $(8,9)$. In vitro systems for studying the role of E1/E2 in HCV entry and neutralization have been developed. Cell culture infectious $\mathrm{HCV}$ (HCVcc) can be produced in cell lines of hepatic origin and yields particles that share many similarities with ex vivo derived HCV (10-12). HCVcc recombinants encoding at least the structural proteins Core, E1 and E2 of a given HCV isolate, but depending on the unique replication capabilities of the JFH1 isolate (13), typically do not require cell culture adaptive envelope mutations (14-19), thus making these HCVcc recombinants particularly useful in studies of entry and neutralization. Such recombinants, including marker viruses, have been developed for major genotypes 1-7 $(2,20,21)$.

Another model, used primarily for the study of HCV entry and neutralization, is HCV pseudo-particles (HCVpp), in which lentiviral or retroviral particles harbor authentic $\mathrm{HCV}$ envelope proteins (22-24). However, these particles are produced in nonhepatic $293 \mathrm{~T}$ cells and therefore lack lipoprotein-association, potentially introducing additional bias in the in vivo relevance of obtained results. For example, many studies have shown that HCV particles associate with apolipoproteins, mainly ApoE, ApoCI, ApoAI, and debatably, ApoB (25-30). This is likely explained by the fact that HCV hijacks the verylow-density lipoprotein (VLDL) production machinery of the infected hepatocyte for virion production (30). In fact, HCV particles from patients and HCVcc systems display low density in gradients due to similarities with VLDL, whereas this is not the case with HCVpp (31-34). A study found that ApoE decreased accessibility of E2 neutralization epitopes (35). In addition, both ApoE and ApoCI appear to facilitate rapid virus entry, which promotes neutralizing antibody $(\mathrm{NAb})$ resistance by decreasing time spent in the extracellular environment (36-38).

Initial attachment of $\mathrm{HCV}$ to the target hepatocyte has been shown to depend on virion-associated ApoE interacting with cell-surface expressed syndecan-1, syndecan-2 and $\mathrm{T}$ cell immunoglobulin and mucin domain-containing protein 1 (3941). Following attachment, the HCV particle interacts with important entry co-receptors, such as scavenger receptor class B, type I (SR-BI), and CD81 (13, 14, 18, 23, 42-45). In addition, HCV relies on additional co-receptors, such as lowdensity lipoprotein receptor (LDLr) (46-48) and the late-stage entry receptors claudin-I and occludin $(49,50)$. Most recently, cellular factors that modulate HCV co-receptor localization and possibly prime the cell for infection have also been described (51-55). While it has been reported that LDLr may facilitate non-infectious uptake of HCV (48), it seems clear that the receptor must play an important role in infectious uptake, as recently confirmed for a number of HCV co-receptors, including LDLr (56). In addition, one study found redundancy in HCV entry dependency for SR-BI and LDLr, suggesting some overlap in function (57). As will be reviewed in the following sections evidence is mounting that the early entry co-receptors LDLr, and particularly SR-BI, are involved in HCV antibody evasion, possibly in an interplay with CD81 $(45,58-61)$.

Patient studies have found that an early induction of HCVspecific NAbs is correlated with resolving HCV infection (62-65). However, the virus employs mechanisms to avoid NAbs. The high mutation rate of $\mathrm{HCV}$, due to the error-prone polymerase NS5B, permits continuous escape from NAb responses (66, 67). On a global scale, this heterogeneity has resulted in the emergence of six epidemiologically important genotypes and numerous clinically relevant subtypes $(2,6,7)$. This has important implications for treatment and vaccine development, but this topic is outside the scope of this review. HCV also avoids NAbs by the capacity for cell-to-cell spread (68) and association with apolipoproteins as mentioned above (35-38, 69). Finally, HCV NAb sensitivity is intrinsically modulated by incompletely understood properties of E1/E2, such as envelope polymorphisms (70-73), N-linked glycans (the glycan shield) (74-77) and hypervariable region 1 (HVR1) at the N-terminus of E2 $(58,78,79)$ (Figure 1A).

The study of the role of HVR1 in the HCV life cycle is a great example of how methodological breakthroughs advance and refine scientific questions. The development of HCVpp and HCVcc models $(13,14,22-24)$, as well as the advent of novel tools, such as comprehensive panels of monoclonal antibodies with non-overlapping E1/E2 epitopes (80-91), have facilitated an increasing number of studies that improve understanding of the role of HVR1 in important aspects of the HCV life cycle, particularly immune evasion and viral entry.

\section{CHARACTERIZATION OF HVR1 IN PATIENT STUDIES}

Shortly after the discovery of HCV, sequencing efforts identified the N-terminus of E2 as a hotspot of sequence variation, and it was termed HVR1 (92-94). The length of HVR1 was initially debated, but has since been agreed to be 27 amino acids long (amino acids 384-410 in the H77 reference strain), except for some subtypes of genotype 6 in which it appears to typically be 26 amino acids. In patients, HVR1 begins accumulating substitutions in the acute phase of infection $(95,96)$ and continues evolving during chronic infection (94, 97-99). The reason for this has been the subject of debate. One study, finding no evidence of positive selection and no correlation between evolutionary rate and HVR1-specific antibody responses in patients, suggested that random drift might be the cause for HVR1 variation (100). However, many studies did observe strong positive selection of $\mathrm{HCV}$, particularly in HVR1 (101-103) and a large body of data now supports that HVR1 variation is due to antibody-driven immune selection. 
A

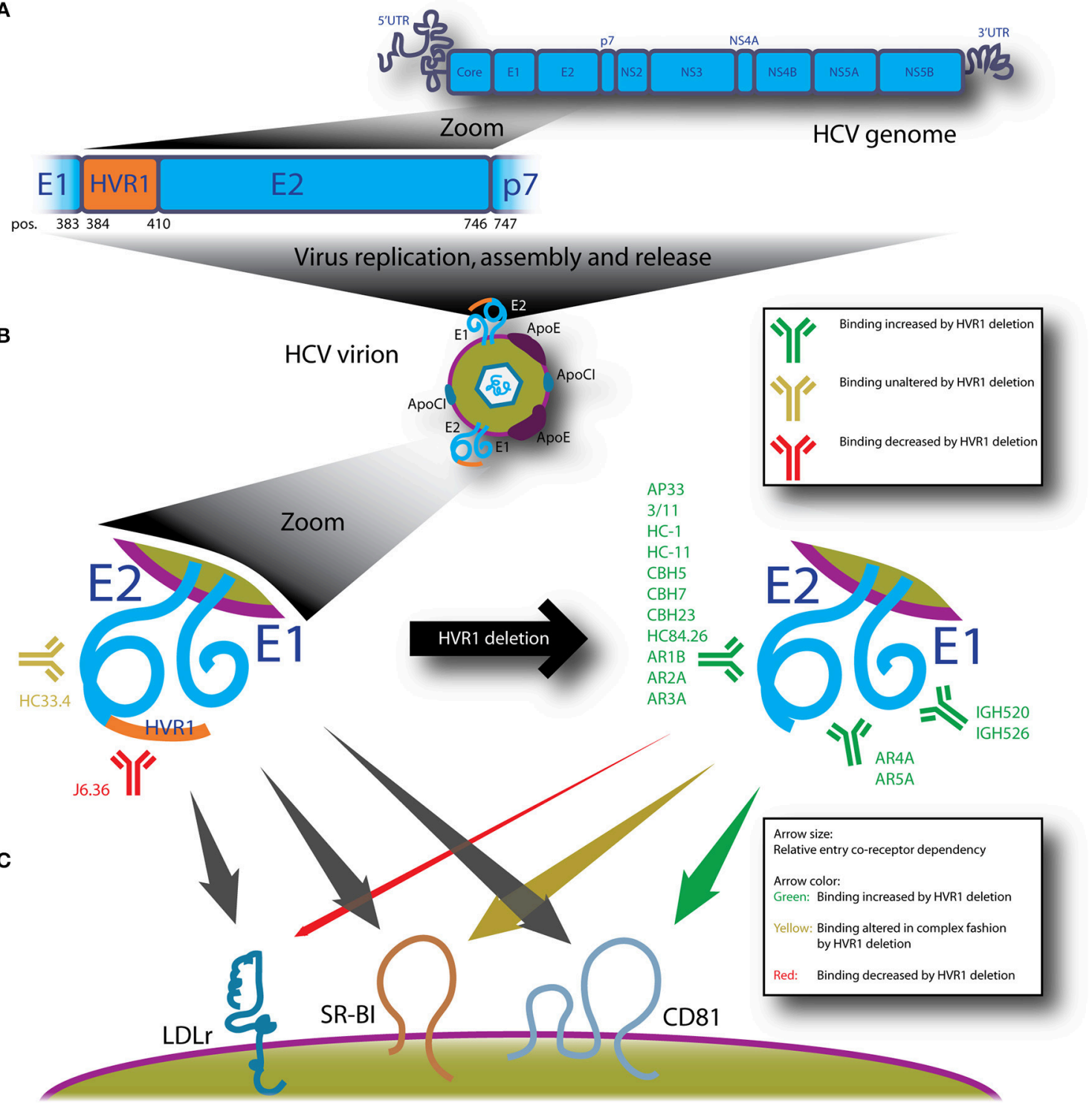

Cell membrane

FIGURE 1 | HVR1 of HCV is located at the N-terminus of E2 and protects the virus from diverse neutralizing antibodies and modulates entry interactions with LDLr, SR-BI and CD81. (A) Depicts HCV genome organization with a zoom of E2 showing that HVR1 corresponds to the $27 \mathrm{~N}$-terminal amino acids of E2 (H77 reference sequence; amino acid position 384-410). (B) Replication of the HCV genome in a permissive cell leads to assembly and release of HCV virions with the E1/E2 complex embedded in the viral envelope. For HVR1-deleted HCV, sensitivity to NAbs is dramatically altered as compiled from multiple studies referenced in the text of this review. Monoclonal NAbs shown are part of comprehensive panels mentioned in the introduction and their specificities are: E1 (IGH520 and IGH526), E2; HVR1 (J6.36), E2; antigenic domain B (CBH5, HC-1 and HC-11), E2; antigenic domain C (CBH7 and CBH23), E2; antigenic domain D (HC84.26), E2; antigenic domain E/epitope I (AP33, 3/11, HC33.4), E2; antigenic region 1 (AR1B), E2; antigenic region 2 (AR2A), E2; antigenic region 3 (AR3A), E1/E2; antigenic region 4 (AR4A) and E1/E2; antigenic region 5 (AR5A). (C) HVR1-deleted HCV interacts differently with entry co-receptors LDLr, SR-BI and CD81, both in terms of dependency for entry (size of arrows) and how readily binding to the receptors occurs (color of arrow). Data is compiled from multiple studies cited in the text on the effects of deleting HVR1 from HCVcc, HCVpp or expressed forms of E2 or E1/E2.

Firstly, antibodies against HVR1 are commonly detectable in chronically infected patients (37, 104-110) and the early induction of such antibodies is associated with acute selflimited infection (111). Interestingly, an early reduction in HVR1 sequence diversity is associated with acute self-limited infection (112), suggesting that a rapid anti-HVR1 response curtails virus proliferation before the virus is able to adequately establish a virus population in the host from which to adapt (e.g., diversify the HVR1 sequence). Secondly, although HVR1 variants are, at least to some extent, able to co-exist with 
the antibodies that recognize them $(98,106,110,113)$, emerging HVR1 variants have been found to have decreased reactivity with autologous patient serum antibodies, indicating that these variants represent escape $(98,106,110,113,114)$. In addition, with the advent of the HCVpp entry model, HVR1 variants emerging in patients have been shown to be directly responsible for decreased in vitro neutralization with homologous serum (64). Finally, HVR1 variation is decreased or non-existent in $\mathrm{HCV}$-infected patients with various types of immunoglobulin deficiencies (115-119).

The neutralization epitopes in HVR1, responsible for this antibody-driven hypervariability, seem to commonly reside in the C-terminus of the region $(98,106,120,121)$. Interestingly, despite the extremely high sequence diversity of HVR1, significant cross-reactivity of patient antibodies between HVR1 variants has been reported (104, 106-108). This may be because HVR1 contains highly conserved positions, such as conserved hydrophobic and positively charged residues, indicating functional constraints on HVR1 evolution (122).

\section{CHARACTERIZATION OF HVR1 IN STUDIES OF EXPERIMENTALLY INFECTED CHIMPANZEES}

Chimpanzees represent the first infection model of $\mathrm{HCV}$ and it has been used extensively to study $\mathrm{HCV}$ pathogenesis (123-125), including the role of HVR1. Incubation of hyper-immune serum raised against HVR1 peptide with a well-characterized homologous $\mathrm{HCV}$ chimpanzee inoculum prevented acute $\mathrm{HCV}$ infection in chimpanzees in one out of two cases (126), thus identifying HVR1 as the first HCV neutralization epitope. Interestingly, a minor variant of the inoculum had a different, serum-resistant, HVR1 sequence and this variant became dominant in the non-protected animal. It is therefore not surprising that anti-HVR1 antibodies in chimpanzees have been associated with HVR1 sequence variation (127), although HVR1 apparently does accumulate sequence changes more slowly in HCV-infected chimpanzees than it does in humans (128). This is likely due to subtle differences in HCV infection of chimpanzees compared with the human infection $(129,130)$, most notably the lower, and typically late, anti-HCV antibody response in chimpanzees (131).

Interestingly, it was possible to infect chimpanzees by intrahepatic injection of HCV RNA with the HVR1 coding sequence deleted (132), resulting in acute infections, which in one case became an attenuated chronic infection. It was since shown that the animals had not raised NAbs and, in fact, that the chimpanzee that cleared acute infection with HVR1-deleted HCV could be chronically infected with the homologous virus following re-challenge (133). These studies confirm that NAbs are not critical for preventing chronic infection in chimpanzees and that HVR1 is not essential for HCV infectivity and persistence in vivo.

\section{HVR1 PROTECTS HCV FROM NEUTRALIZING ANTIBODIES}

It was initially discovered that E2 expressed on the surface of cells did not appear to lose proper folding upon deletion of HVR1 (134). Subsequently it was shown that chimpanzees could be acutely and chronically infected with HCV by intrahepatic injection with HVR1-deleted HCV RNA transcripts, although infection was attenuated (132). With the advent of the HCVpp model of HCV entry it became possible to perform detailed studies of viral entry and neutralization $(22,23)$, but the deletion of HVR1 in the HCVpp model decreased infectivity 10 to $100-$ fold, making it challenging to study $(44,60)$. However, HVR1deleted HCVpp was found to have increased susceptibility to NAbs targeting cross-subtype conserved epitopes (78), suggesting a role of HVR1 in NAb protection.

These studies were complemented with the advent of the HCVcc model $(13,14)$. The removal of HVR1 from HCVcc harboring E1/E2 from multiple isolates, including genotype $1-3,5$, and 6 , had very different effects on culture viability (79). Some recombinant viruses were only slightly attenuated, whereas the fitness of others depended on one or two adaptive envelope substitutions, and the genotype 4 a recombinant was non-viable $(58,79)$. Interestingly, while the H77(1a) envelope substitutions identified in the HCVcc model rescued infectivity of the HVR1-deleted H77 HCVpp, the opposite was true for HVR1-deleted S52(3a) HCVpp, in which the HCVcc adaptive envelope substitution decreased HCVpp infectivity even further (60). However, in all cases the resultant HVR1-deleted HCVcc displayed dramatically increased sensitivity to HCV NAbs and patient sera $(58,79)$. This phenomenon was initially believed to mainly involve epitopes that overlapped with the CD81 binding site of E2 (58), but it was recently shown that HVR1 protects a much wider variety of epitopes, such as antigenic regions 1-5 (AR1-5; on E2 and E1/E2), antigenic domains B-E (on E2) and even E1 epitopes (135) (Figure 1B). An exception to the broad increase in sensitivity is that viruses with and without HVR1 were similarly sensitive to the antigenic domain E antibody, HC33.4, and it has been suggested that this might indicate that HVR1 does not protect certain epitopes within antigenic domain E (136). However, it should be noted that HC33.4 has a secondary contact residue at position 408 within HVR1 (137), which could explain why HVR1-deleted viruses were not more sensitive to this antibody. The breadth in epitopes protected by HVR1 makes it less likely that direct steric epitope shielding alone accounts for the observed differences in NAb sensitivity of HCV with and without HVR1, but more studies are needed to address this in detail. Importantly, the ability of HVR1 to protect HCV from NAbs was recently confirmed in vivo by infusing HCV-permissive human liver chimeric mice with antibodies from a chronically infected patient prior to challenge using mouse pools of $\mathrm{HCV}$ with and without HVR1 (11).

The broad NAb-sensitizing effect of removing HVR1 has enabled the use of HVR1-deleted viruses to study virus escape in culture using lower doses of NAb than would otherwise have been needed (138). Although resistance substitutions identified in this manner for NAb AR5A were relevant for $\mathrm{HCVcc}$ retaining 
HVR1 (138), clear differences were observed in similar studies for $\mathrm{NAb} \mathrm{AR} 4 \mathrm{~A}$, which also appeared to have a higher barrier to resistance (139). It was recently found that HVR1-mediated $\mathrm{NAb}$ protection could be increased even further through the binding of HVR1-specific antibodies, possibly by increased steric occlusion mediated by HVR1-bound antibody (137). The HVR1mediated NAb protection may function in concert with other highly variable region in E2 $(140,141)$, but how this interplay functions is largely unknown.

A related mechanism by which HVR1 has been proposed to protect $\mathrm{HCV}$ from NAbs is in serving as a decoy epitope, diverting the humoral immune system away from more conserved epitopes. This is supported by the correlation between persistence and higher non-synonymous to synonymous substitution rates in HVR1 (142), thus indicating that HVR1directed immune responses can help the virus persist. The observed positive selection of HVR1 (101-103), combined with studies of HVR1 variants in immune-complexed HCV further supports this hypothesis $(143,144)$. In addition, the appearance of HVR1-specific antibodies in patient sera was associated with emergence of immune-complexes of particles carrying that specific HVR1 sequence, leading to a large reduction of that viral population within the patient (144). The idea that HVR1 contains immuno-dominant antibody epitopes with a high propensity for accumulating fitness-permissive escape substitutions fits well with the idea that HVR1 also protects other NAb epitopes on E1/E2. It could be hypothesized that immuno-dominance would be a possible consequence of the aforementioned epitope protection.

\section{IN VITRO STUDIES OF THE ROLE OF HVR1 IN HCV ENTRY}

SR-BI was identified as a possible $\mathrm{HCV}$ co-receptor by its ability to interact with soluble E2 (43). It was also found that HVR1-deleted soluble E2 protein lost most of the ability to interact with this receptor (43), although the interaction could be restored by the introduction of HVR1-deletion adaptive envelope substitutions previously identified in vivo $(43,132)$. These findings suggested that HVR1 modulates SR-BI interaction, but may not be directly interacting with SR-BI. The fact that an antibody against HVR1 blocked soluble E2 binding with SR-BI (43) is not proof of an HVR1/SR-BI interaction as the antibody could be sterically interfering with the SR-BI/E2 interaction without binding directly to the SR-BI binding site, much like the binding of antibody to an epitope tag on E2 neutralized tagged HCV (145). It was subsequently shown that HVR1-deleted soluble E2 more effectively bound CD81 (146). The advent of the HCVpp model confirmed CD81 $(23,44)$, and SR-BI $(44)$ as coreceptors of $\mathrm{HCV}$ entry and facilitated in depth studies of their role in this process.

It was discovered that the human serum component, high density lipoprotein (HDL), enhanced HCVpp infectivity and this phenomenon was confirmed in multiple ways to be both HVR1 and SR-BI dependent $(78,147)$. In addition, HDL appeared to decrease NAb sensitivity of $\operatorname{HCVpp}(78,148)$, possibly by increased speed of viral entry, thus minimizing the window during which neutralization could occur (149). These findings were corroborated in HCVcc studies $(45,148,149)$. In parallel with these studies it was found that the HDL component, ApoCI, was sufficient to induce HCV infection enhancement (37). Interestingly, it appeared that ApoCI was transferred from HDL to HCV in an HVR1 and SR-BI dependent fashion, linked with the native lipid transfer function of the receptor (38). HDL does not interact directly with $\mathrm{HCV}$ in the absence of SR-BI $(147,149)$, but free ApoCI is able to do so, thus bypassing SRBI (38). In fact, low doses of free ApoCI confer enhancement, while high ApoCI doses destabilize the virus, potentially through modulating virion fusogenicity (38).

SR-BI/HCV interaction was confirmed with $\mathrm{HCV}$ particles derived from human serum (150). However, this interaction did not depend on E2, but rather VLDL-like properties of these particles (150), most likely virion-associated ApoE. The fact that the interaction with SR-BI was energy-dependent and that suramin (a compound that reduces ApoE/receptor interaction) could not decrease the HCV/SR-BI association suggested that SRBI might serve a role in endocytosis (150). However, the results could also be explained by secondary E2/SR-BI interactions, which might not be inhibited by suramin. HCVcc, which unlike HCVpp, is associated with apolipoproteins like ApoE, was used to address this possibility (151). It was found that the lipid-transfer function of SR-BI was critical for infection, but particles with densities above $1.1 \mathrm{~g} / \mathrm{ml}$ depended on SRBI specifically for cell attachment (151). While both these phenomena were independent of E2/SR-BI interaction, a third interaction involving a complex HVR1/E2/SR-BI/HDL interplay to enhance infectivity of HCV was also described (151), which is in line with findings from studies of HCVpp and HCVcc outlined above.

In addition, ApoE was found to be associated with $\mathrm{HCV}$ both with and without HVR1, but may serve different roles in the interaction with SR-BI $(59,60)$. While the nature of these differences remains unclear it is tempting to speculate that the high density HVR1-deleted particles interact with SR-BI through ApoE, as shown to be the case for high-density HCV retaining HVR1 (151). The fact that temporal blocking of CD81 and SR-BI yield similar HCV entry inhibition profiles may suggest that these $\mathrm{HCV} /$ receptor interactions are closely linked in time $(45,61)$, further stressing the possibility that SR-BI interactions lead to exposure of the CD81 binding site and downstream entry events.

It was found that the removal of HVR1 greatly increases accessibility of the CD81 binding site on E2 $(58,59)$. While HVR1 did not appear to modulate late-stage HCV entry co-receptor dependency for claudin-I and occludin, it did appear to influence the ability of HCV to interact with SR-BI (59). However, another study found that HVR1-deletion adaptive envelope mutations were responsible for altered SR-BI dependency as opposed to the deletion of HVR1 itself (60). Non-HVR1 E2 determinants of SRBI binding would also be better in line with the fact that HVR1deleted soluble E2 binding to SR-BI could be rescued by envelope mutations (43).

The part of HVR1 involved in modulating these processes, including the ability of HVR1 to protect HCV from NAbs, 
was since narrowed down to polyprotein positions 400-408 in the HCVpp model (121) and found to include conserved basic residues in HVR1, such as R408. However, in the HCVcc model it was also found that changing the $\mathrm{N}$-terminal position 385 of HVR1 broadly influenced NAb sensitivity (152). It seems clear that intrinsic properties of the HVR1 sequence helps determine the level of HVR1-mediated NAb protection (120), but to what degree this depends on E1/E2 properties outside of HVR1 remains to be determined. Interestingly, many of the effects of removing or mutating HVR1 can be reproduced by the introduction of point mutations outside of HVR1 (153-155), suggesting the existence of non-HVR1 determinants.

HVR1 has also been proposed to interact with glycosaminoglycans in the HCVpp model, thus suggesting a role in attachment (156). However, the HCVpp model is typically deficient in ApoE, which is now believed to be the primary mediator of $\mathrm{HCV}$ attachment $(39,40)$, suggesting the results may not be as relevant for native HCV. Finally, HVR1-deleted HCV was shown to have decreased LDLr entry dependency $(59,60)$. In addition, HVR1-deleted HCVcc particles lost most of the ability to interact with soluble LDLr, suggesting a role of HVR1 in the interaction (60). Thus, HVR1 modulates the interaction of $\mathrm{HCV}$ with no less than three entry co-receptors (Figure 1C). Not surprisingly, several open questions remain, both with regards to receptor usage and NAb protection.

\section{FUTURE PERSPECTIVES FOR DEFINING THE ROLE OF HVR1}

HVR1 apparently modulates interactions with no less than three HCV entry co-receptors, which may explain the functional constraints on HVR1 evolution. In addition, the inherent high variability of HVR1 permits it to serve as a rapidly changing decoy epitope, while directly protecting the virus from NAbs targeting a wide array of both conserved and less conserved E1/E2 epitopes. Not surprisingly, the deletion of HVR1 from soluble E2 protein fails to fully recapitulate these effects, which severely impairs reliability of molecular interaction studies and modeling. The structural flexibility of HVR1 has so far hindered crystallography studies of E2 protein retaining HVR1 $(157,158)$ and consequently we know very little about how this important

\section{REFERENCES}

1. World Health Organization. Hepatitis C. Fact Sheet Number 164. WHO (2017). Available online at: http://www.who.int/mediacentre/factsheets/ fs164/en/

2. Bukh J. The history of hepatitis $\mathrm{C}$ virus (HCV): basic research reveals unique features in phylogeny, evolution and the viral life cycle with new perspectives for epidemic control. J Hepatol. (2016) 65:S2-21. doi: 10.1016/j.jhep.2016.07.035

3. Pawlotsky JM, Feld JJ, Zeuzem S, Hoofnagle JH. From non-A, nonB hepatitis to hepatitis C virus cure. J Hepatol. (2015) 62:S87-99. doi: 10.1016/j.jhep.2015.02.006

4. Zoulim F, Liang TJ, Gerbes AL, Aghemo A, Deuffic-Burban S, Dusheiko G, et al. Hepatitis $\mathrm{C}$ virus treatment in the real world: optimising treatment region interacts with the remaining part of E2. Being able to produce and study a recombinantly expressed, native (i.e., as it sits in the virus membrane) E1/E2 heterodimer is urgently needed to further elucidate the contentious multi-functionality of HVR1 at a molecular level. The lack of native recombinant E1/E2 is also likely why the obvious interest in using HVR1-deleted vaccine candidates, in which conserved epitopes should be more exposed and consequently more immunogenic, has yielded conflicting results $(159,160)$. It is likely also evidence for the fact that HVR1 multi-functionality is dependent on the E1/E2 context on the virion. However, little is known about how much of the effect of HVR1 on NAb sensitivity and receptor dependency is intrinsic to the HVR1 sequence and how much depends on the E1/E2 context. In addition, the interplay between E1/E2 $\mathrm{NAb}$ protection caused by polymorphisms, $\mathrm{N}$-linked glycans and HVR1 is virtually unknown. Such studies should offer a novel way to insights on how HVR1 serves its many functions, including the capacity to protect such a wide array of NAb epitopes.

The research on the role of HVR1 in the HCV viral lifecycle and host responses remains highly relevant, but despite great advances in our understanding of this unique genome region for $\mathrm{HCV}$, particularly during the past 15 years, many questions remain. Providing answers to the role of HVR1 may prove critical in designing a successful HCV vaccine and stemming this global epidemic.

\section{AUTHOR CONTRIBUTIONS}

All authors listed have made a substantial, direct and intellectual contribution to the work, and approved it for publication.

\section{ACKNOWLEDGMENTS}

We would like to thank Bjarne Ørskov Lindhardt (Copenhagen University Hospital, Hvidovre) and Carsten Geisler (University of Copenhagen) for valuable support. We further thank the Region H Foundation, The Danish Cancer Society, The AP Møller Foundation, The Lundbeck Foundation, The Novo Nordisk Foundation, The Danish Council for Independent Research (DFF), and Innovation Fund Denmark for supporting the CO-HEP studies cited in this review. JB is the recipient of the 2015 Novo Nordisk Prize. and access to therapies. Gut (2015) 64:1824-33. doi: 10.1136/gutjnl-2015310421

5. Bartenschlager R, Baumert TF, Bukh J, Houghton M, Lemon SM, Lindenbach $\mathrm{BD}$, et al. Critical challenges and emerging opportunities in hepatitis $\mathrm{C}$ virus research in an era of potent antiviral therapy: considerations for scientists and funding agencies. Virus Res. (2018) 248:5362. doi: 10.1016/j.virusres.2018.02.016

6. Simmonds P, Becher P, Bukh J, Gould EA, Meyers G, Monath T, et al. ICT. V. Virus taxonomy profile: flaviviridae. J Gen.Virol. (2017) 98:2-3. doi: 10.1099/jgv.0.000672

7. Smith DB, Becher P, Bukh J, Gould EA, Meyers G, Monath T, et al. Proposed update to the taxonomy of the genera Hepacivirus and Pegivirus within the Flaviviridae family. J Gen.Virol. (2016) 97:2894-07. doi: 10.1099/jgv.0. 000612 
8. Deleersnyder V, Pillez A, Wychowski C, Blight K, Xu J, Hahn YS, et al. Formation of native hepatitis C virus glycoprotein complexes. J Virol. (1997) 71:697-704.

9. Op de Beeck A, Voisset C, Bartosch B, Ciczora Y, Cocquerel L, Keck Z, et al. Characterization of functional hepatitis $\mathrm{C}$ virus envelope glycoproteins. $J$ Virol. (2004) 78:2994-3002. doi: 10.1128/JVI.78.6.2994-3002.2004

10. Lindenbach BD, Meuleman P, Ploss A, Vanwolleghem T, Syder AJ, McKeating JA, et al. Cell culture-grown hepatitis $\mathrm{C}$ virus is infectious in vivo and can be recultured in vitro. Proc Natl Acad Sci USA. (2006) 103:3805-09. doi: 10.1073/pnas.0511218103

11. Prentoe J, Verhoye L, Velazquez MR, Buysschaert C, Farhoudi A, Wang R, et al. HVR1-mediated antibody evasion of highly infectious in vivo adapted HCV in humanised mice. Gut (2016) 65:1988-97. doi: 10.1136/gutjnl-2015-310300

12. Ramirez S, Bukh J. Current status and future development of infectious cellculture models for the major genotypes of hepatitis $\mathrm{C}$ virus: essential tools in testing of antivirals and emerging vaccine strategies. Antiviral Res. (2018) 158:264-87. doi: 10.1016/j.antiviral.2018.07.014

13. Wakita T, Pietschmann T, Kato T, Date T, Miyamoto M, Zhao Z, et al. Production of infectious hepatitis $\mathrm{C}$ virus in tissue culture from a cloned viral genome. Nat Med. (2005) 11:791-6. doi: 10.1038/nm1268

14. Lindenbach BD, Evans MJ, Syder AJ, Wolk B, Tellinghuisen TL, Liu CC, et al. Complete replication of hepatitis C virus in cell culture. Science (2005) 309:623-26. doi: 10.1126/science.1114016

15. Gottwein JM, Scheel TK, Hoegh AM, Lademann JB, Eugen-Olsen J, Lisby $\mathrm{G}$, et al. Robust hepatitis C genotype 3 a cell culture releasing adapted intergenotypic 3a/2a (S52/JFH1) viruses. Gastroenterology (2007) 133:161426. doi: 10.1053/j.gastro.2007.08.005

16. Jensen TB, Gottwein JM, Scheel TK, Hoegh AM, Eugen-Olsen J, Bukh J. Highly efficient JFH1-based cell-culture system for hepatitis C virus genotype 5a: failure of homologous neutralizing-antibody treatment to control infection. J Infect Dis. (2008) 198:1756-65. doi: 10.1086/593021

17. Scheel TK, Gottwein JM, Jensen TB, Prentoe JC, Hoegh AM, Alter HJ, et al. Development of JFH1-based cell culture systems for hepatitis C virus genotype $4 \mathrm{a}$ and evidence for cross-genotype neutralization. Proc Natl Acad Sci USA. (2008) 105:997-1002. doi: 10.1073/pnas.0711044105

18. Gottwein JM, Scheel TK, Jensen TB, Lademann JB, Prentoe JC, Knudsen ML, et al. Development and characterization of hepatitis $C$ virus genotype 1-7 cell culture systems: role of CD81 and scavenger receptor class B type I and effect of antiviral drugs. Hepatology (2009) 49:364-77. doi: 10.1002/hep.22673

19. Pietschmann T, Kaul A, Koutsoudakis G, Shavinskaya A, Kallis S, Steinmann E, et al. Construction and characterization of infectious intragenotypic and intergenotypic hepatitis C virus chimeras. Proc Natl Acad Sci USA. (2006) 103:7408-13. doi: 10.1073/pnas.0504877103

20. Carlsen TH, Pedersen J, Prentoe JC, Giang E, Keck ZY, Mikkelsen LS, et al. Breadth of neutralization and synergy of clinically relevant human monoclonal antibodies against HCV genotypes $1 \mathrm{a}, 1 \mathrm{~b}, 2 \mathrm{a}, 2 \mathrm{~b}, 2 \mathrm{c}$, and $3 \mathrm{a}$. Hepatology (2014) 60:1551-62. doi: 10.1002/hep.27298

21. Gottwein JM, Jensen TB, Mathiesen CK, Meuleman P, Serre SB, Lademann $\mathrm{JB}$, et al. Development and application of hepatitis $\mathrm{C}$ reporter viruses with genotype 1 to 7 core-nonstructural protein 2 (NS2) expressing fluorescent proteins or luciferase in modified JFH1 NS5A. J Virol. (2011) 85:8913-28. doi: 10.1128/JVI.00049-11

22. Bartosch B, Dubuisson J, Cosset FL. Infectious hepatitis C virus pseudoparticles containing functional E1-E2 envelope protein complexes. J Exp Med. (2003) 197:633-42. doi: 10.1084/jem.20021756

23. Hsu M, Zhang J, Flint M, Logvinoff C, Cheng-Mayer C, Rice CM, et al. Hepatitis $\mathrm{C}$ virus glycoproteins mediate $\mathrm{pH}$-dependent cell entry of pseudotyped retroviral particles. Proc Natl Acad Sci USA. (2003) 100:727176. doi: 10.1073/pnas.0832180100

24. Drummer HE, Maerz A, Poumbourios P. Cell surface expression of functional hepatitis C virus E1 and E2 glycoproteins. FEBS Lett. (2003) 546:385-90. doi: 10.1016/S0014-5793(03)00635-5

25. Chang KS, Jiang J, Cai Z, Luo G. Human apolipoprotein e is required for infectivity and production of hepatitis C virus in cell culture. J Virol. (2007) 81:13783-793. doi: 10.1128/JVI.01091-07

26. Merz A, Long G, Hiet MS, Brugger B, Chlanda P, Andre P, et al. Biochemical and morphological properties of hepatitis $\mathrm{C}$ virus particles and determination of their lipidome. J Biol Chem. (2011) 286:3018-32. doi: 10.1074/jbc.M110.175018

27. Catanese MT, Uryu K, Kopp M, Edwards TJ, Andrus L, Rice WJ, et al. Ultrastructural analysis of hepatitis C virus particles. Proc Natl Acad Sci USA. (2013) 110:9505-10. doi: 10.1073/pnas.1307527110

28. Meunier JC, Russell RS, Engle RE, Faulk KN, Purcell RH, Emerson, SU. Apolipoprotein c1 association with hepatitis C virus. J Virol. (2008) 82:964756. doi: 10.1128/JVI.00914-08

29. Jiang J, Luo G. Apolipoprotein E but not B is required for the formation of infectious hepatitis C virus particles. J Virol. (2009) 83:12680-91. doi: 10.1128/JVI.01476-09

30. Huang H, Sun F, Owen DM, Li W, Chen Y, Gale M, et al. Hepatitis C virus production by human hepatocytes dependent on assembly and secretion of very low-density lipoproteins. Proc Natl Acad Sci USA. (2007) 104:5848-53. doi: 10.1073 /pnas.0700760104

31. Gastaminza P, Kapadia SB, Chisari FV. Differential biophysical properties of infectious intracellular and secreted hepatitis C virus particles. J Virol. (2006) 80:11074-81. doi: 10.1128/JVI.01150-06

32. Andre P, Komurian-Pradel F, Deforges S, Perret M, Berland JL, Sodoyer $\mathrm{M}$, et al. Characterization of low- and very-low-density hepatitis C virus RNA-containing particles. J Virol. (2002) 76:6919-28. doi: 10.1128/JVI.76.14.6919-6928.2002

33. Nielsen SU, Bassendine MF, Burt AD, Martin C, Pumeechockchai W, Toms GL. Association between hepatitis C virus and very-low-density lipoprotein (VLDL)/LDL analyzed in iodixanol density gradients. J Virol. (2006) 80:2418-28. doi: 10.1128/JVI.80.5.2418-2428.2006

34. Podevin P, Carpentier A, Pene V, Aoudjehane L, Carriere M, Zaidi S, et al. Production of infectious hepatitis C virus in primary cultures of human adult hepatocytes. Gastroenterology (2010) 139:1355-64. doi: 10.1053/j.gastro.2010.06.058

35. Fauvelle C, Felmlee DJ, Crouchet E, Lee J, Heydmann L, Lefevre $\mathrm{M}$, et al. Apolipoprotein $\mathrm{E}$ mediates evasion from hepatitis C virus neutralizing antibodies. Gastroenterology (2016) 150:206-217. doi: 10.1053/j.gastro.2015.09.014

36. Bankwitz D, Doepke M, Hueging K, Weller R, Bruening J, Behrendt P, et al. Maturation of secreted HCV particles by incorporation of secreted ApoE protects from antibodies by enhancing infectivity. J Hepatol. (2017) 67:480-89. doi: 10.1016/j.jhep.2017.04.010

37. Meunier JC, Engle RE, Faulk K, Zhao M, Bartosch B, Alter H, et al. Evidence for cross-genotype neutralization of hepatitis $\mathrm{C}$ virus pseudo-particles and enhancement of infectivity by apolipoprotein C1. Proc Natl Acad Sci USA. (2005) 102:4560-65. doi: 10.1073/pnas.0501275102

38. Dreux M, Boson B, Ricard-Blum S, Molle J, Lavillette D, Bartosch B, et al. The exchangeable apolipoprotein ApoC-I promotes membrane fusion of hepatitis C virus. J Biol Chem. (2007) 282:32357-69. doi: 10.1074/jbc.M705358200

39. Shi Q, Jiang J, Luo G. Syndecan-1 serves as the major receptor for attachment of hepatitis C virus to the surfaces of hepatocytes. J Virol. (2013) 87:6866-75. doi: 10.1128/JVI.03475-12

40. Jiang J, Cun W, Wu X, Shi Q, Tang H, Luo G. Hepatitis C virus attachment mediated by apolipoprotein E binding to cell surface heparan sulfate. J Virol. (2012) 86:7256-67. doi: 10.1128/JVI.07222-11

41. Wang J, Qiao L, Hou Z, Luo G. TIM-1 promotes hepatitis C virus cell attachment and infection. J Virol. (2017) 91:e01583-16. doi: 10.1128/JVI.01583-16

42. Pileri P, Uematsu Y, Campagnoli S, Galli G, Falugi F, Petracca R, et al. Binding of hepatitis C virus to CD81. Science (1998) 282:938-41. doi: $10.1126 /$ science. 282.5390 .938

43. Scarselli E, Ansuini H, Cerino R, Roccasecca RM, Acali S, Filocamo $\mathrm{G}$, et al. The human scavenger receptor class $\mathrm{B}$ type $\mathrm{I}$ is a novel candidate receptor for the hepatitis C virus. EMB O J. (2002) 21:5017-25. doi: 10.1093/emboj/cdf529

44. Bartosch B, Vitelli A, Granier C, Goujon C, Dubuisson J, Pascale S, et al. Cell entry of hepatitis $C$ virus requires a set of co-receptors that include the CD81 tetraspanin and the SR-B1 scavenger receptor. J Biol Chem. (2003) 278:41624-30. doi: 10.1074/jbc.M305289200

45. Zeisel MB, Koutsoudakis G, Schnober EK, Haberstroh A, Blum HE, Cosset $\mathrm{FL}$, et al. Scavenger receptor class B type I is a key host factor for hepatitis C 
virus infection required for an entry step closely linked to CD81. Hepatology (2007) 46:1722-31. doi: 10.1002/hep.21994

46. Agnello V, Abel G, Elfahal M, Knight GB, Zhang QX. Hepatitis C virus and other flaviviridae viruses enter cells via low density lipoprotein receptor. Proc Natl Acad Sci USA. (1999) 96:12766-771. doi: 10.1073/pnas.96.22.12766

47. Molina S, Castet V, Fournier-Wirth C, Pichard-Garcia L, Avner R, Harats D, et al. The low-density lipoprotein receptor plays a role in the infection of primary human hepatocytes by hepatitis C virus. J.Hepatol. (2007) 46:41119. doi: 10.1016/j.jhep.2006.09.024

48. Albecka A, Belouzard S, Op de BA, Descamps V, Goueslain L, BertrandMichel J, et al. Role of low-density lipoprotein receptor in the hepatitis $\mathrm{C}$ virus life cycle. Hepatology (2012) 55:998-1007. doi: 10.1002/hep.25501

49. Evans MJ, von HT, Tscherne DM, Syder AJ, Panis M, Wolk B, et al. Claudin1 is a hepatitis $\mathrm{C}$ virus co-receptor required for a late step in entry. Nature (2007) 446:801-5. doi: 10.1038/nature05654

50. Ploss A, Evans MJ, Gaysinskaya VA, Panis M, You H, de Jong YP, et al. Human occludin is a hepatitis $\mathrm{C}$ virus entry factor required for infection of mouse cells. Nature (2009) 457:882-86. doi: 10.1038/nature07684

51. Riva L, Song OR, Prentoe J, Helle F, L'homme L, Gattolliat CH, et al. Identification of piperazinylbenzenesulfonamides as new inhibitors of Claudin-1 trafficking and hepatitis C virus entry. J Virol. (2018) 92:e0198217. doi: 10.1128/JVI.01982-17

52. Sainz B, Barretto N, Martin DN, Hiraga N, Imamura M, Hussain S, et al. Identification of the Niemann-Pick C1-like 1 cholesterol absorption receptor as a new hepatitis C virus entry factor. Nat Med. (2012) 18:281-285. doi: $10.1038 / \mathrm{nm} .2581$

53. Lupberger J, Zeisel MB, Xiao F, Thumann C, Fofana I, Zona L, et al. EGFR and EphA2 are host factors for hepatitis $C$ virus entry and possible targets for antiviral therapy. Nat Med. (2011) 17:589-95. doi: 10.1038/nm.2341

54. Wu X, Lee EM, Hammack C, Robotham JM, Basu M, Lang J, et al. Cell deathinducing DFFA-like effector $\mathrm{b}$ is required for hepatitis $\mathrm{C}$ virus entry into hepatocytes. J Virol. (2014) 88:8433-44. doi: 10.1128/JVI.00081-14

55. Sekhar V, Pollicino T, Diaz G, Engle RE, Alayli F, Melis M, et al. Infection with hepatitis $C$ virus depends on TACSTD2, a regulator of claudin-1 and occludin highly downregulated in hepatocellular carcinoma. PLoS Pathog. (2018) 14:e1006916. doi: 10.1371/journal.ppat.1006916

56. Fan H, Qiao L, Kang KD, Fan J, Wei W, Luo G. Attachment and postattachment receptors important for hepatitis $\mathrm{C}$ virus infection and cellto-cell transmission. J Virol. (2017) 91:e00280-17. doi: 10.1128/JVI.00280-17

57. Yamamoto S, Fukuhara T, Ono C, Uemura K, Kawachi Y, Shiokawa M, et al. Lipoprotein receptors redundantly participate in entry of hepatitis $\mathrm{C}$ virus. PLoS Pathog. (2016) 12:e1005610. doi: 10.1371/journal.ppat.1005610

58. Bankwitz D, Steinmann E, Bitzegeio J, Ciesek S, Friesland M, Herrmann E, et al. Hepatitis $\mathrm{C}$ virus hypervariable region 1 modulates receptor interactions, conceals the CD81 binding site, and protects conserved neutralizing epitopes. J Virol. (2010) 84:5751-63. doi: 10.1128/JVI.02200-09

59. Bankwitz D, Vieyres G, Hueging K, Bitzegeio J, Doepke M, Chhatwal $\mathrm{P}$, et al. Role of hypervariable region 1 for the interplay of hepatitis $\mathrm{C}$ virus with entry factors and lipoproteins. J Virol. (2014) 88:12644-655. doi: 10.1128/JVI.01145-14

60. Prentoe J, Serre SB, Ramirez S, Nicosia A, Gottwein JM, Bukh J. Hypervariable region 1 deletion and required adaptive envelope mutations confer decreased dependency on scavenger receptor class B type I and lowdensity lipoprotein receptor for hepatitis C virus. J Virol. (2014) 88:1725-39. doi: 10.1128/JVI.02017-13

61. Kapadia SB, Barth H, Baumert T, McKeating JA, Chisari FV. Initiation of hepatitis $\mathrm{C}$ virus infection is dependent on cholesterol and cooperativity between CD81 and scavenger receptor B type I. J Virol. (2007) 81:374-83. doi: 10.1128/JVI.01134-06

62. Osburn WO, Snider AE, Wells BL, Latanich R, Bailey JR, Thomas DL, et al. Clearance of hepatitis $\mathrm{C}$ infection is associated with the early appearance of broad neutralizing antibody responses. Hepatology (2014) 59:2140-51. doi: 10.1002/hep.27013

63. Pestka JM, Zeisel MB, Blaser E, Schurmann P, Bartosch B, Cosset FL, et al. Rapid induction of virus-neutralizing antibodies and viral clearance in a single-source outbreak of hepatitis C. Proc Natl Acad Sci USA. (2007) 104:6025-30. doi: 10.1073/pnas.0607026104
64. Dowd KA, Netski DM, Wang XH, Cox AL, Ray SC. Selection pressure from neutralizing antibodies drives sequence evolution during acute infection with hepatitis C virus. Gastroenterology (2009) 136:2377-86. doi: 10.1053 /j.gastro.2009.02.080

65. Lavillette D, Morice Y, Germanidis G, Donot P, Soulier A, Pagkalos E, et al. Human serum facilitates hepatitis $C$ virus infection, and neutralizing responses inversely correlate with viral replication kinetics at the acute phase of hepatitis C virus infection. J Virol. (2005) 79:6023-34. doi: 10.1128/JVI.79.10.6023-6034.2005

66. von Hahn T, Yoon JC, Alter H, Rice CM, Rehermann B, Balfe P, et al. Hepatitis C virus continuously escapes from neutralizing antibody and Tcell responses during chronic infection in vivo. Gastroenterology (2007) 132:667-78. doi: 10.1053/j.gastro.2006.12.008

67. Shimizu YK, Hijikata M, Iwamoto A, Alter HJ, Purcell RH, Yoshikura H. Neutralizing antibodies against hepatitis $\mathrm{C}$ virus and the emergence of neutralization escape mutant viruses. J Virol. (1994) 68:1494-500.

68. Timpe JM, Stamataki Z, Jennings A, Hu K, Farquhar MJ, Harris HJ, et al. Hepatitis C virus cell-cell transmission in hepatoma cells in the presence of neutralizing antibodies. Hepatology (2008) 47:17-24. doi: 10.1002/hep.21959

69. Wrensch F, Crouchet E, Ligat G, Zeisel MB, Keck ZY, SFoung KH, et al. Hepatitis C Virus (HCV)-apolipoprotein interactions and immune evasion and their impact on HC. V. vaccine design. Front Immunol. (2018) 9:1436. doi: 10.3389/fimmu.2018.01436

70. Bailey JR, Wasilewski LN, Snider AE, El-Diwany R, Osburn WO, Keck $\mathrm{Z}$, et al. Naturally selected hepatitis C virus polymorphisms confer broad neutralizing antibody resistance. J Clin Invest. (2015) 125:437-47. doi: 10.1172/JCI78794

71. Wasilewski LN, El-Diwany R, Munshaw S, Snider AE, Brady JK, Osburn WO, et al. A Hepatitis C virus envelope polymorphism confers resistance to neutralization by polyclonal sera and broadly neutralizing monoclonal antibodies. J Virol. (2016) 90:3773-82. doi: 10.1128/JVI.02837-15

72. El-Diwany R, Cohen VJ, Mankowski MC, Wasilewski LN, Brady JK, Snider $\mathrm{AE}$, et al. Extra-epitopic hepatitis $\mathrm{C}$ virus polymorphisms confer resistance to broadly neutralizing antibodies by modulating binding to scavenger receptor B1. PLoS Pathog. (2017) 13:e1006235. doi: 10.1371/journal.ppat.1006235

73. Kinchen VJ, Bailey JR. Defining breadth of hepatitis C virus neutralization. Front Immunol. (2018) 9:1703. doi: 10.3389/fimmu.2018.01703

74. Helle F, Goffard A, Morel V, Duverlie G, McKeating J, Keck ZY, et al. The neutralizing activity of anti-hepatitis $C$ virus antibodies is modulated by specific glycans on the E2 envelope protein. J Virol. (2007) 81:8101-11. doi: 10.1128/JVI.00127-07

75. Helle F, Vieyres G, Elkrief L, Popescu CI, Wychowski C, Descamps V, et al. Role of $\mathrm{N}$-linked glycans in the functions of hepatitis $\mathrm{C}$ virus envelope proteins incorporated into infectious virions. J Virol. (2010) 84:11905-15. doi: 10.1128/JVI.01548-10

76. Falkowska E, Kajumo F, Garcia E, Reinus J, Dragic T. Hepatitis C virus envelope glycoprotein E2 glycans modulate entry, CD81 binding, and neutralization. J Virol. (2007) 81:8072-79. doi: 10.1128/JVI.00459-07

77. Lavie M, Hanoulle X, Dubuisson J. Glycan shielding and modulation of hepatitis C virus neutralizing antibodies. Front Immunol. (2018) 9:910. doi: 10.3389/fimmu.2018.00910

78. Bartosch B, Verney G, Dreux M, Donot P, Morice Y, Penin F, et al. An interplay between hypervariable region 1 of the hepatitis C virus E2 glycoprotein, the scavenger receptor BI, and highdensity lipoprotein promotes both enhancement of infection and protection against neutralizing antibodies. J Virol. (2005) 79:8217-29. doi: 10.1128/JVI.79.13.8217-8229.2005

79. Prentoe J, Jensen TB, Meuleman P, Serre SB, Scheel TK, Leroux-Roels G, et al. Hypervariable region 1 differentially impacts viability of hepatitis $C$ virus strains of genotypes 1 to 6 and impairs virus neutralization. J Virol. (2011) 85:2224-34. doi: 10.1128/JVI.01594-10

80. Meunier JC, Russell RS, Goossens V, Priem S, Walter H, Depla E, et al. Isolation and characterization of broadly neutralizing human monoclonal antibodies to the el glycoprotein of hepatitis C virus. J Virol. (2008) 82:96673. doi: 10.1128/JVI.01872-07

81. Keck ZY, Op de BA, Hadlock KG, Xia J, Li TK, Dubuisson J, et al. Hepatitis $\mathrm{C}$ virus $\mathrm{E} 2$ has three immunogenic domains containing conformational 
epitopes with distinct properties and biological functions. J Virol. (2004) 78:9224-32. doi: 10.1128/JVI.78.17.9224-9232.2004

82. Keck ZY, Xia J, Wang Y, Wang W, Krey T, Prentoe J, et al. Human monoclonal antibodies to a novel cluster of conformational epitopes on HC. V. E2 with resistance to neutralization escape in a genotype 2a isolate. PLoS Pathog. (2012) 8:e1002653. doi: 10.1371/journal.ppat.1002653

83. Keck Z, Wang W, Wang Y, Lau P, Carlsen TH, Prentoe J, et al. Cooperativity in virus neutralization by human monoclonal antibodies to two adjacent regions located at the amino terminus of hepatitis $\mathrm{C}$ virus E2 glycoprotein. $J$ Virol. (2013) 87:37-51. doi: 10.1128/JVI.01941-12

84. Law M, Maruyama T, Lewis J, Giang E, Tarr AW, Stamataki Z, et al. Broadly neutralizing antibodies protect against hepatitis $\mathrm{C}$ virus quasispecies challenge. Nat Med. (2008) 14:25-7. doi: 10.1038/n m1698

85. Giang E, Dorner M, Prentoe JC, Dreux M, Evans MJ, Bukh J, et al. Human broadly neutralizing antibodies to the envelope glycoprotein complex of hepatitis C virus. Proc Natl Acad Sci USA. (2012) 109:6205-10. doi: 10.1073/pnas.1114927109

86. Hadlock KG, Lanford RE, Perkins S, Rowe J, Yang Q, Levy S, et al. Human monoclonal antibodies that inhibit binding of hepatitis $\mathrm{C}$ virus E2 protein to CD81 and recognize conserved conformational epitopes. J Virol. (2000) 74:10407-16. doi: 10.1128/JVI.74.22.10407-10416.2000

87. Keck ZY, Li TK, Xia J, Gal-Tanamy M, Olson O, Li SH, et al. Definition of a conserved immunodominant domain on hepatitis C virus E2 glycoprotein by neutralizing human monoclonal antibodies. J Virol. (2008) 82:6061-6. doi: 10.1128/JVI.02475-07

88. Sabo MC, Luca VC, Prentoe J, Hopcraft SE, Blight KJ, Yi M, et al. Neutralizing monoclonal antibodies against hepatitis $\mathrm{C}$ virus E2 protein bind discontinuous epitopes and inhibit infection at a postattachment step. J Virol. (2011) 85:7005-19. doi: 10.1128/JVI.00586-11

89. Owsianka A, Tarr AW, Juttla VS, Lavillette D, Bartosch B, Cosset FL, et al. Monoclonal antibody AP33 defines a broadly neutralizing epitope on the hepatitis C virus E2 envelope glycoprotein. J Virol. (2005) 79:11095-104. doi: 10.1128/JVI.79.17.11095-11104.2005

90. Tarr AW, Owsianka AM, Timms JM, McClure CP, Brown RJ, Hickling TP, et al. Characterization of the hepatitis $\mathrm{C}$ virus E2 epitope defined by the broadly neutralizing monoclonal antibody AP33. Hepatology (2006) 43:592-601. doi: $10.1002 /$ hep. 21088

91. Keck ML, Wrensch F, Pierce BG, Baumert TF, Foung SKH. Mapping determinants of virus neutralization and viral escape for rational design of a hepatitis C virus vaccine. Front Immunol. (2018) 9:1194. doi: 10.3389/fimmu.2018.01194

92. Weiner AJ, Brauer MJ, Rosenblatt J, Richman KH, Tung J, Crawford $\mathrm{K}$, et al. Variable and hypervariable domains are found in the regions of $\mathrm{HCV}$ corresponding to the flavivirus envelope and NS1 proteins and the pestivirus envelope glycoproteins. Virology (1991) 180:842-8. doi: 10.1016/0042-6822(91)90104-J

93. Hijikata M, Kato N, Ootsuyama $Y$, Nakagawa M, Ohkoshi S, Shimotohno K. Hypervariable regions in the putative glycoprotein of hepatitis C virus. Biochem Biophys Res Commun. (1991) 175:220-8. doi: 10.1016/S0006-291X(05)81223-9

94. Ogata N, Alter HJ, Miller RH, Purcell RH. Nucleotide sequence and mutation rate of the H strain of hepatitis C virus. Proc Natl Acad Sci USA. (1991) 88:3392-6. doi: 10.1073/pnas.88.8.3392

95. Enomoto N, Sakamoto N, Kurosaki M, Marumo F, Sato C. The hypervariable region of the $\mathrm{HCV}$ genome changes sequentially during the progression of acute HCV infection to chronic hepatitis. J Hepatol. (1993) 17:415-6. doi: 10.1016/S0168-8278(05)80226-0

96. Sakamoto N, Enomoto N, Kurosaki M, Marumo F, Sato C. Sequential change of the hypervariable region of the hepatitis $\mathrm{C}$ virus genome in acute infection. J Med Virol. (1994) 42:103-8. doi: 10.1002/jmv.1890420119

97. Kurosaki M, Enomoto N, Marumo F, Sato C. Rapid sequence variation of the hypervariable region of hepatitis $\mathrm{C}$ virus during the course of chronic infection. Hepatology (1993) 18:1293-9. doi: 10.1002/hep.1840180602

98. Weiner AJ, Geysen HM, Christopherson C, Hall JE, Mason TJ, Saracco G, et al. Evidence for immune selection of hepatitis $\mathrm{C}$ virus (HCV) putative envelope glycoprotein variants: potential role in chronic $\mathrm{HCV}$ infections. Proc Natl Acad Sci USA. (1992) 89:3468-72. doi: 10.1073/pnas.89.8.3468
99. McAllister J, Casino C, Davidson F, Power J, Lawlor E, Yap PL, et al. Long-term evolution of the hypervariable region of hepatitis $\mathrm{C}$ virus in a common-source-infected cohort. J Virol. (1998) 72:4893-905.

100. Allain JP, Dong Y, Vandamme AM, Moulton V, Salemi M. Evolutionary rate and genetic drift of hepatitis $\mathrm{C}$ virus are not correlated with the host immune response: studies of infected donor-recipient clusters. J Virol. (2000) 74:2541-9. doi: 10.1128/JVI.74.6.2541-2549.2000

101. Palmer BA, Schmidt-Martin D, Dimitrova Z, Skums P, Crosbie O, KennyWalsh E, et al. Network analysis of the chronic hepatitis $\mathrm{C}$ virome defines hypervariable region 1 evolutionary phenotypes in the context of humoral immune responses. J Virol. (2015) 90:3318-29. doi: 10.1128/JVI.02995-15

102. Schmidt-Martin D, Crosbie O, Kenny-Walsh E, Fanning LJ. Intensive temporal mapping of hepatitis $\mathrm{C}$ hypervariable region 1 quasispecies provides novel insights into hepatitis $\mathrm{C}$ virus evolution in chronic infection. J Gen Virol. (2015) 96:2145-56. doi: 10.1099/vir.0.000149

103. Cuevas JM, Gonzalez M, Torres-Puente M, Jimenez-Hernandez N, Bracho MA, Garcia-Robles I, et al. The role of positive selection in hepatitis $\mathrm{C}$ virus. Infect Genet Evol. (2009) 9:860-6. doi: 10.1016/j.meegid.2009.05.007

104. Jackson P, Petrik J, Alexander GJ, Pearson G, Allain JP. Reactivity of synthetic peptides representing selected sections of hepatitis $\mathrm{C}$ virus core and envelope proteins with a panel of hepatitis C virus-seropositive human plasma. J Med Virol. (1997) 51:67-79.

105. Zibert A, Kraas W, Meisel H, Jung G, Roggendorf M. Epitope mapping of antibodies directed against hypervariable region 1 in acute self-limiting and chronic infections due to hepatitis C virus. J Virol. (1997) 71:4123-7.

106. Scarselli E, Cerino A, Esposito G, Silini E, Mondelli MU, Traboni C. Occurrence of antibodies reactive with more than one variant of the putative envelope glycoprotein (gp70) hypervariable region 1 in viremic hepatitis C virus-infected patients. J Virol. (1995) 69:4407-12.

107. da Silva CM, Siemoneit K, Nemecek V, Epple S, Koerner K, Kubanek B. The serology of hepatitis $\mathrm{C}$ virus (HCV) infection: antibody crossreaction in the hypervariable region 1. Arch Virol. (1995) 140:1705-13. doi: 10.1007/BF01384335

108. Mondelli MU, Cerino A, Lisa A, Brambilla S, Segagni L, Cividini A, et al. Antibody responses to hepatitis $\mathrm{C}$ virus hypervariable region 1: evidence for cross-reactivity and immune-mediated sequence variation. Hepatology (1999) 30:537-45. doi: 10.1002/hep.510300233

109. Brambilla S, Bellati G, Asti M, Lisa A, Candusso ME, D’Amico M, et al. Dynamics of hypervariable region 1 variation in hepatitis $\mathrm{C}$ virus infection and correlation with clinical and virological features of liver disease. Hepatology (1998) 27:1678-86. doi: 10.1002/hep.510270629

110. Kato N, Sekiya H, Ootsuyama Y, Nakazawa T, Hijikata M, Ohkoshi S, et al. Humoral immune response to hypervariable region 1 of the putative envelope glycoprotein (gp70) of hepatitis C virus. J Virol. (1993) 67:3923-30.

111. Zibert A, Meisel H, Kraas W, Schulz A, Jung G, Roggendorf M. Early antibody response against hypervariable region 1 is associated with acute self-limiting infections of hepatitis C virus. Hepatology (1997) 25:1245-9. doi: 10.1002/hep. 510250530

112. Farci P, Shimoda A, Coiana A, Diaz G, Peddis G, Melpolder JC, et al. The outcome of acute hepatitis $\mathrm{C}$ predicted by the evolution of the viral quasispecies. Science (2000) 288:339-44. doi: 10.1126/science.288.5464.339

113. Taniguchi S, Okamoto H, Sakamoto M, Kojima M, Tsuda F, Tanaka T, et al. A structurally flexible and antigenically variable $\mathrm{N}$-terminal domain of the hepatitis $\mathrm{C}$ virus E2/NS1 protein: implication for an escape from antibody. Virology (1993) 195:297-301. doi: 10.1006/viro.1993.1378

114. Kato N, Ootsuyama Y, Sekiya H, Ohkoshi S, Nakazawa T, Hijikata M, et al. Genetic drift in hypervariable region 1 of the viral genome in persistent hepatitis C virus infection. J Virol. (1994) 68:4776-84.

115. Kumar U, Monjardino J, Thomas HC. Hypervariable region of hepatitis C virus envelope glycoprotein (E2/NS1) in an agammaglobulinemic patient. Gastroenterology (1994) 106:1072-5. doi: 10.1016/0016-5085(94)90770-6

116. Odeberg J, Yun Z, Sonnerborg A, Bjoro K, Uhlen M, Lundeberg J. Variation of hepatitis $\mathrm{C}$ virus hypervariable region 1 in immunocompromised patients. J Infect Dis. (1997) 175:938-43. doi: 10.1086/513995

117. Booth JC, Kumar U, Webster D, Monjardino J, Thomas HC. Comparison of the rate of sequence variation in the hypervariable region of E2/NS1 region of hepatitis $\mathrm{C}$ virus in normal and hypogammaglobulinemic patients. Hepatology (1998) 27:223-7. doi: 10.1002/hep.510270134 
118. Gaud U, Langer B, Petropoulou T, Thomas HC, Karayiannis P. Changes in hypervariable region 1 of the envelope 2 glycoprotein of hepatitis $\mathrm{C}$ virus in children and adults with humoral immune defects. J Med Virol. (2003) 69:350-6. doi: 10.1002/jmv.10296

119. Lee WM, Polson JE, Carney DS, Sahin B, Gale M Jr. Reemergence of hepatitis $\mathrm{C}$ virus after 8.5 years in a patient with hypogammaglobulinemia: evidence for an occult viral reservoir. J Infect Dis. (2005) 192:1088-92. doi: $10.1086 / 432917$

120. Vieyres G, Dubuisson J, Patel AH. Characterization of antibody-mediated neutralization directed against the hypervariable region 1 of hepatitis $C$ virus E2 glycoprotein. J Gen Virol. (2011) 92:494-506. doi: 10.1099/vir.0.028092-0

121. Guan M, Wang W, Liu X, Tong Y, Liu Y, Ren H, et al. Three different functional microdomains in the hepatitis $\mathrm{C}$ virus hypervariable region 1 (HVR1) mediate entry and immune evasion. J Biol Chem. (2012) 287:3563145. doi: 10.1074/jbc.M112.382341

122. Penin F, Combet C, Germanidis G, Frainais PO, Deleage G, Pawlotsky JM. Conservation of the conformation and positive charges of hepatitis C virus E2 envelope glycoprotein hypervariable region 1 points to a role in cell attachment. J Virol. (2001) 75:5703-10. doi: 10.1128/JVI.75.12.5703-5710.2001

123. Bukh J. A critical role for the chimpanzee model in the study of hepatitis C. Hepatology (2004) 39:1469-75. doi: 10.1002/hep.20268

124. Bukh J, Forns X, Emerson SU, Purcell RH. Studies of hepatitis C virus in chimpanzees and their importance for vaccine development. Intervirology (2001) 44:132-42. doi: 10.1159/000050040

125. Lanford RE, Walker CM, Lemon SM. The chimpanzee model of viral hepatitis: advances in understanding the immune response and treatment of viral hepatitis. ILAR J. (2017) 58:172-89. doi: 10.1093/ilar/ilx028

126. Farci P, Shimoda A, Wong D, Cabezon T, De GD, Strazzera A, et al. Prevention of hepatitis $C$ virus infection in chimpanzees by hyperimmune serum against the hypervariable region 1 of the envelope 2 protein. Proc Natl Acad Sci USA. (1996) 93:15394-9. doi: 10.1073/pnas.93.26.15394

127. van Doorn LJ, Capriles I, Maertens G, DeLeys R, Murray K, Kos T, et al. Sequence evolution of the hypervariable region in the putative envelope region E2/NS1 of hepatitis $\mathrm{C}$ virus is correlated with specific humoral immune responses. J Virol. (1995) 69:773-8.

128. Ray SC, Mao Q, Lanford RE, Bassett S, Laeyendecker O, Wang YM, et al. Hypervariable region 1 sequence stability during hepatitis C virus replication in chimpanzees. J Virol. (2000) 74:3058-66. doi: 10.1128/JVI.74.7.3058-3066.2000

129. Bassett SE, Brasky KM, Lanford, RE. Analysis of hepatitis C virus-inoculated chimpanzees reveals unexpected clinical profiles. J Virol. (1998) 72:2589-99.

130. Alter MJ, Margolis HS, Krawczynski K, Judson FN, Mares A, Alexander WJ, et al. The natural history of community-acquired hepatitis $\mathrm{C}$ in the United States. The sentinel counties chronic nonA, non-B hepatitis study team. N Engl J Med. (1992) 327:1899-905. doi: 10.1056/NEJM199212313272702

131. Bassett SE, Thomas DL, Brasky KM, Lanford RE. Viral persistence, antibody to $\mathrm{E} 1$ and $\mathrm{E} 2$, and hypervariable region 1 sequence stability in hepatitis $\mathrm{C}$ virus-inoculated chimpanzees. J Virol. (1999) 73:1118-26.

132. Forns X, Thimme R, Govindarajan S, Emerson SU, Purcell RH, Chisari FV, et al. Hepatitis $\mathrm{C}$ virus lacking the hypervariable region 1 of the second envelope protein is infectious and causes acute resolving or persistent infection in chimpanzees. Proc Natl Acad Sci USA. (2000) 97:13318-23. doi: 10.1073/pnas.230453597

133. Bukh J, Thimme R, Meunier JC, Faulk K, Spangenberg HC, Chang $\mathrm{KM}$, et al. Previously infected chimpanzees are not consistently protected against reinfection or persistent infection after reexposure to the identical hepatitis C virus strain. J Virol. (2008) 82:8183-95. doi: 10.1128/JVI.00 142-08

134. Forns X, Allander T, Rohwer-Nutter P, Bukh J. Characterization of modified hepatitis C virus E2 proteins expressed on the cell surface. Virology (2000) 274:75-85. doi: 10.1006/viro.2000.0419

135. Prentoe J, Velazquez-Moctezuma R, Foung SK, Law M, Bukh J. Hypervariable region 1 shielding of hepatitis $C$ virus is a main contributor to genotypic differences in neutralization sensitivity. Hepatology (2016) 64:1881-92. doi: 10.1002/hep.28705
136. Bankwitz D, Pietschmann T. Hepatitis C virus plays hide and seek with neutralizing antibodies. Hepatology (2016) 64:1840-2. doi: 10.1002/hep.28760

137. Keck ZY, Girard-Blanc C, Wang W, Lau P, Zuiani A, Rey FA, et al. Antibody response to hypervariable region 1 interferes with broadly neutralizing antibodies to hepatitis C virus. J Virol. (2016) 90:3112-22. doi: 10.1128/JVI.02458-15

138. Velazquez-Moctezuma R, Law M, Bukh J, Prentoe J. Applying antibodysensitive hypervariable region 1-deleted hepatitis $C$ virus to the study of escape pathways of neutralizing human monoclonal antibody AR5A. PLoS Pathog. (2017) 13:e1006214. doi: 10.1371/journal.ppat.1006214

139. Velazquez-Moctezuma R, Galli A, Law M, Bukh J, Prentoe J. Hepatitis C virus escape studies for human monoclonal antibody AR4A reveal isolatespecific resistance and a high barrier to resistance. J Infect Dis. (2018). doi: 10.1093/infdis/jiy481. [Epub ahead of print].

140. McCaffrey K, Boo I, Owczarek CM, Hardy MP, Perugini MA, Fabri L, et al. An optimized hepatitis $\mathrm{C}$ virus $\mathrm{E} 2$ glycoprotein core adopts a functional homodimer that efficiently blocks virus entry. J Virol. (2017) 91:e01668-16. doi: 10.1128/JVI.01668-16

141. Alhammad Y, Gu J, Boo I, Harrison D, McCaffrey K, Vietheer PT, et al. Monoclonal antibodies directed toward the hepatitis $\mathrm{C}$ virus glycoprotein E2 detect antigenic differences modulated by the N-terminal hypervariable region 1 (HVR1), HVR2, and intergenotypic variable region. J Virol. (2015) 89:12245-261. doi: 10.1128/JVI.02070-15

142. Ray SC, Wang YM, Laeyendecker O, Ticehurst JR, Villano SA, Thomas DL. Acute hepatitis $\mathrm{C}$ virus structural gene sequences as predictors of persistent viremia: hypervariable region 1 as a decoy. J Virol. (1999) 73:2938-46.

143. Korenaga M, Hino K, Okazaki M, Okuda M, Okita K. Differences in hypervariable region 1 quasispecies between immune complexed and non-immune complexed hepatitis C virus particles. Biochem Biophys Res Commun. (1997) 240:677-82. doi: 10.1006/bbrc.1997.7693

144. Korenaga M, Hino K, Katoh Y, Yamaguchi Y, Okuda M, Yoshioka K, et al. A possible role of hypervariable region 1 quasispecies in escape of hepatitis C virus particles from neutralization. J Viral Hepat. (2001) 8:331-40. doi: 10.1046/j.1365-2893.2001.00305.x

145. Prentoe J, Bukh J. Hepatitis C virus expressing flag-tagged envelope protein 2 has unaltered infectivity and density, is specifically neutralized by flag antibodies and can be purified by affinity chromatography. Virology (2011) 409:148-55. doi: 10.1016/j.virol.2010.10.034

146. Roccasecca R, Ansuini H, Vitelli A, Meola A, Scarselli E, Acali S, et al. Binding of the hepatitis C virus E2 glycoprotein to CD81 is strain specific and is modulated by a complex interplay between hypervariable regions 1 and 2 . J Virol. (2003) 77:1856-67. doi: 10.1128/JVI.77.3.1856-1867.2003

147. Voisset C, Callens N, Blanchard E, Op de BA, Dubuisson J, Vu-Dac N. High density lipoproteins facilitate hepatitis C virus entry through the scavenger receptor class B type I. J Biol Chem. (2005) 280:7793-99. doi: 10.1074/jbc.M411600200

148. Voisset C, Op de BA, Horellou P, Dreux M, Gustot T, Duverlie G, et al. High-density lipoproteins reduce the neutralizing effect of hepatitis $\mathrm{C}$ virus (HCV)-infected patient antibodies by promoting HCV entry. J Gen Virol. (2006) 87:2577-81. doi: 10.1099/vir.0.81932-0

149. Dreux M, Pietschmann T, Granier C, Voisset C, Ricard-Blum S, Mangeot $\mathrm{PE}$, et al. High density lipoprotein inhibits hepatitis $\mathrm{C}$ virus-neutralizing antibodies by stimulating cell entry via activation of the scavenger receptor BI. J Biol Chem. (2006) 281:18285-95. doi: 10.1074/jbc.M602706200

150. Maillard P, Huby T, Andreo U, Moreau M, Chapman J, Budkowska A. The interaction of natural hepatitis $\mathrm{C}$ virus with human scavenger receptor SR$\mathrm{BI} / \mathrm{Cla} 1$ is mediated by ApoB-containing lipoproteins. FASE B J. (2006) 20:735-37. doi: 10.1096/fj.05-4728fje

151. Dao TV, Granier C, Zeisel MB, Guerin M, Mancip J, Granio O, et al. Characterization of hepatitis $\mathrm{C}$ virus particle subpopulations reveals multiple usage of the scavenger receptor BI for entry steps. J Biol Chem. (2012) 287:31242-57. doi: 10.1074/jbc.M112.365924

152. Mathiesen CK, Prentoe J, Meredith LW, Jensen TB, Krarup H, McKeating JA, et al. Adaptive mutations enhance assembly and cell-to-cell transmission of a high-titer hepatitis c virus genotype 5a Core-NS2 JFH1-based recombinant. J Virol. (2015) 89:7758-75. doi: 10.1128/JVI.00039-15 
153. Grove J, Nielsen S, Zhong J, Bassendine MF, Drummer HE, Balfe P, et al. Identification of a residue in hepatitis C virus E2 glycoprotein that determines scavenger receptor BI and CD81 receptor dependency and sensitivity to neutralizing antibodies. J Virol. (2008) 82:12020-29. doi: 10.1128/JVI.01569-08

154. Dhillon S, Witteveldt J, Gatherer D, Owsianka AM, Zeisel MB, Zahid $\mathrm{MN}$, et al. Mutations within a conserved region of the hepatitis C virus E2 glycoprotein that influence virus-receptor interactions and sensitivity to neutralizing antibodies. J Virol. (2010) 84:5494-07. doi: 10.1128/JVI.02153-09

155. Tao W, Xu C, Ding Q, Li R, Xiang Y, Chung J, et al. A single point mutation in $\mathrm{E} 2$ enhances hepatitis $\mathrm{C}$ virus infectivity and alters lipoprotein association of viral particles. Virology (2009) 395:67-76. doi: 10.1016/j.virol.2009.09.006

156. Basu A, Beyene A, Meyer K, Ray R. The hypervariable region 1 of the E2 glycoprotein of hepatitis $C$ virus binds to glycosaminoglycans, but this binding does not lead to infection in a pseudotype system. J Virol. (2004) 78:4478-86. doi: 10.1128/JVI.78.9.4478-4486.2004

157. Khan AG, Whidby J, Miller MT, Scarborough H, Zatorski AV, Cygan A, et al. Structure of the core ectodomain of the hepatitis $\mathrm{C}$ virus envelope glycoprotein 2. Nature (2014) 509:381-4. doi: 10.1038/nature13117

158. Kong L, Giang E, Nieusma T, Kadam RU, Cogburn KE, Hua Y, et al. Hepatitis C virus E2 envelope glycoprotein core structure. Science (2013) 342:1090-4. doi: $10.1126 /$ science. 1243876
159. Law JLM, Logan M, Wong J, Kundu J, Hockman D, Landi A, et al. Role of the E2 hypervariable region (HVR1) in the immunogenicity of a recombinant hepatitis C virus vaccine. J.Virol. (2018) 92:e02141-17. doi: 10.1128/JVI.02141-17

160. Vietheer PT, Boo I, Gu J, McCaffrey K, Edwards S, Owczarek C, et al. The core domain of hepatitis $\mathrm{C}$ virus glycoprotein E2 generates potent cross-neutralizing antibodies in guinea pigs. Hepatology (2017) 65:1117-31. doi: $10.1002 /$ hep. 28989

Conflict of Interest Statement: The authors declare that the research was conducted in the absence of any commercial or financial relationships that could be construed as a potential conflict of interest.

The reviewer FW and handling editor declared their shared affiliation at the time of review.

Copyright (๑) 2018 Prentoe and Bukh. This is an open-access article distributed under the terms of the Creative Commons Attribution License (CC BY). The use, distribution or reproduction in other forums is permitted, provided the original author(s) and the copyright owner(s) are credited and that the original publication in this journal is cited, in accordance with accepted academic practice. No use, distribution or reproduction is permitted which does not comply with these terms. 